\title{
PENGETAHUAN MANAJEMEN GURU DALAM MENGELOLA KELAS DI SDIT AL KAUTSAR MADANI
}

\section{Oleh Afi Parnawi \\ STAI Ibnu Sina Batam \\ Email: Affi354@gmail.com}

\begin{abstract}
Guru adalah sumber pengetahuan bagi anak didiknya. Dalam konteks persoalan manajemen kelas, yang dapat dilakukan oleh guru adalah pelaksanaan mengatur pembelajaran secara baik. Penelitian ini berupaya mengungkapkan Peran Guru Dalam Pelaksanaan dan peran dalam mengatasi kendala-kendala manajemen kelas SDIT AI Kautsar Madani Kota Batam. Penelitian menggunakan metode kualitatif yang bersifat deskriptif. Pengumpulan data dengan teknik observasi dan wawancara, adapun yang menjadi informan ialah enam orang guru kelas. Teknik analisis data dengan tahapan: mereduksi data, penyajian data, dan kesimpulan. Hasil penelitian peran guru dalam mengatur manajemen siswa dengan selalu memberi motivasi kepada siswa untuk belajar dengan baik, dan memberikan nashehat. Siswa yang berbuat tidak baik guru memberi teguran, sehingga perilaku siswa yang tidak baik tersebut tidak berkelanjutan, guru kelas di SDIT AI Kautsar Madani Kota Batam sangat berperan dalam merencanakan, mengorganisakan dll, dengan cara guru membina dan membimbing peserta didik sesuai dengan berbagai latar belakang sosial, ekonomi, budaya serta sifat-sifat individunya, membantu peserta didik belajar dan bekerja sesuai dengan potensi dan kemampuan yang dimilikinya, dan mengatasi hambatanhambatan yang menghalangi terwujudnya interaksi dalam kegiatan belajar mengajar.
\end{abstract}

Kata Kunci: Pengetahuan, Manajemen Guru, Mengelola Kelas 


\title{
PENGETAHUAN MANAJEMEN GURU DALAM MENGELOLA KELAS DI SDIT AL KAUTSAR MADANI
}

\author{
Oleh Afi Parnawi \\ STAI Ibnu Sina Batam \\ Email: Affi354@gmail.com
}

\section{Pendahuluan}

Kelas merupakan masalah tingkah laku yang kompleks, dan guru menggunakannya untuk menciptakan dan mempertahankan kondisi kelas sedemikian rupa sehingga anak didik dapat mencapai tujuan pengajaran secara efesien dan memungkinkan mereka dapat belajar. ${ }^{1}$ Guru sangat berperan dalam membantu perkembangan peserta didik untuk mewujudkan tujuan hidupnya secara optimal.Tak ada guru, tidak ada pendidikan, tidak ada pendidikan tidak ada proses pencerdasan, tanpa proses pencerdasan yang bermakna, Statemen ini bermakna bahwa prosesperadaban dan pemanusiaan akan lumpuh tanpa kehadiran guru dalam mentransformasikan proses pembelajaran anak bangsa. $^{2}$

Peranan guru sangat penting dalam pendidikan. Baik buruknya suatu pendidikan dipengaruhi oleh bagaimana seorang guru dapat menyampaikan atau mengajarkan ilmu pengetahuan serta nilai-nilai kehidupan yang mampu membawa peserta didik mewujudkan cita-citanya, baik untuk dirinya, keluarga, masyakarat

\footnotetext{
${ }^{1}$ Syaiful Bahri Djamarah, Strategi belajar mengajar / Syaiful Bahri Djamarah dan Aswan Zain, pertama edition (Jakarta: Rineka cipta, 2010).

${ }^{2}$ Mulyasa, Menjadi Guru Profesional. Bandung (Bandung: Remaja Kosdakarya, 2005).

19 Jurnal Madania: Volume 9 : 1, 2019 (e-ISSN 2620-8210 | p-ISSN 2088-3226
} 


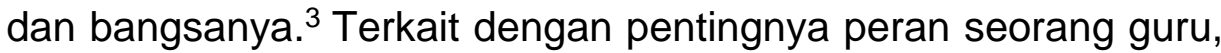
maka seyogyanya guru harus memiliki berbagai kemampuan, tidak hanya kemampuan akademik yang harus dimiliki oleh seorang guru, akan tetapi bagaimana seorang guru mempunyai kemampuan untuk memotivasi peserta didik, agar mau belajar yang nantinya akan meningkatkan prestasi serta cita-cita peserta didik. Lebih spesifiknya lagi peran yang dimaksud disini berkaitan dengan peran guru dalam proses pembelajaran. Guru merupakan faktor penentu yang sangat dominan dalam pendidikan pada umumnya, karena guru memegang peranan dalam proses pembelajaran, dimana proses pembelajaran merupakan inti dari proses pendidikan secara keseluruhan. ${ }^{4}$

Berdasarkan observasi yang dilakukan penulis pada SDIT AI Kautsar Madani Kota Batam. Masih ada guru yang belum maksimal dalam pelaksanaan manajemen kelas. Masih banyaknya siswa yang kurang memperhatikan materi pelajaran serta bermain-main pada saat pelajaran dimulai, sehingga guru sulit untuk memulai pembelajaran, hal ini terjadi dikarenakan kurangnya pengetahuan manajemen guru dalam mengelolaan kelas. Guru tersebut belum sepenuhnya menerapkan komponen manajemen kelas dengan optimal dan kurang memahami teoriteori manajemen kelas sehingga terjadi kesenjangan antara teori dengan kenyataan di kelas.

Hasil pengamatan yang dilakukan, penulis melihat masalah guru-guru tidak sepenuhnya melaksanakan kompenen-kompenen manajemen kelas. Masalah antara lain (a). Perangkat pembelajaran. (b). Mengecek kehadiran (c). Mengumpulkan hasil pekerjaan siswa, memeriksa dan menilai hasil pekerjaan. (d). Pendistribusian alat dan bahan. (e). Mengumpulkan informasi dari siswa. (f). Menyampaikan materi pelajaran. (g). Memberikan tugas.

\footnotetext{
${ }^{3}$ M. Fahli Zatra Hadi and Zubaidah Zubaidah, 'Pemanfaatan Konseling Neuro Linguistic Programming dalam Mengatasi Kesulitan Belajar Siswa Sekolah Dasar', Jurnal Dakwah Risalah, vol. 26, no. 4 (2015), pp. 174-82.

${ }^{4}$ Miftahuddin Miftahuddin and Nofmiyati Nofmiyati, 'NILAI NILAI PENDIDIKAN MORAL DALAM GURINDAM DUA BELAS KARYA RAJA ALI HAJI', An-Nida', vol. 40, no. 2 (2016), pp. 89-99.
} 
Tujuan penelitian yang ingin dicapai dalam penelitian ini yaitu: Untuk mengetahui peran guru dalam pelaksanaan manajemen kelas di SDIT Al Kautsar Madani Kota Batam terlaksana dengan baik. Untuk mengetahui cara mengatasi kendala-kendala dalam pelaksanaan manajemen kelas di SDIT AI Kautsar Madani Kota Batam.

Adapun peranan guru menurut pendapat para ahli berikut yang dikuti dalam buku ${ }^{5}$ adalah:

1. Prey Katz menggambarkan peranan guru sebagai komunikator, sahabat yang dapat memberikan nasihat-nasihat, motivator sebagai pemberi inspirasi dan dorongan, pembimbing dalam pengembangang sikap dan tingkah laku serta nila-nilai, orang yang menguasi bahan yang diajarkan.

2. Havighurstmenjelaskan bahwa peranan guru di sekolah sebagi pegawai (employee) dalam hubungan kedinasan, sebagai bawahan (subordinate) terhadap atasannya, sebagai kolega dalam hubungannya dengan teman sejawat, sebagai mediator dalam hubungannya dengan anak didik, sebagai pengatur disiplin, evaluator dan penganti orang tua.

3. James W. Brownmengemukakan bahwa tugas dan peranan guru antara lain: menguasai dan mengembangkan materi pelajaran, merencana dan mempersiapkan pelajaran sehari-hari, mengontrol dan mengevaluasi kegiatan siswa.

Berdasarkan penjelasan diatas dapat simpulkan bahwa peranan guru dalam proses belajar mengajar begitu besar memberi fasilitas pencapaian tujuan melalui pengalaman belajar yang memadai dan membantu perkembangan aspek-aspek pribadi, seperti sikap, nilainilai, dan penyesuaian diri. Peranan guru dalam kegiatan belajarmengajar, secara singkat dapat disebutkan sebagai berikut: (a), Informator (b) Organisator, (c), Motivator (d), Pengarah (e), Inisiator (f), Transmiter (g), Fasilitator (h), Mediator (i) EvaluatorManajemen atau pengelolaan dalam pengertian umum adalah pengadministrasian, pengaturan dan penataan suatu kegiata. ${ }^{6}$ Sedangkan kelas

\footnotetext{
${ }^{5}$ Sadirman A.M, Interaksi dan Motivasi Belajar Mengajar (Jakarta: Raja Grafindo Persada, 2012).

${ }^{6}$ lbid.

21 Jurnal Madania: Volume 9 : 1, 2019 (e-ISSN 2620-8210| p-ISSN 2088-3226
} 
terkandung suatu pengertian, yaitu sekelompok siswa, yang pada waktu yang sama menerima pengajaran yang sama dari guru yang sama. $^{7}$

Manajemen kelas adalah keterampilan guru untuk menciptakan dan memelihara kondisi belajar yang optimal dan mengembalikannya bila terjadi gangguan dalam proses belajar mengajar. ${ }^{8}$ Berdasarkan uraian diatas dapat disimpulkan bahwa, manajemen kelas adalah keterampilan guru untuk menciptakan dan memelihara kondisi belajar yang optimal sehingga dapat terlaksana kegiatan belajar seperti yang diharapkan. Manajemen kelas adalah usaha guru untuk menciptakan dan mempertahankan kondisi yang memungkinkan pengelolaan pengajaran dapat berlangsung dengan berhasil. ${ }^{9}$ Manajemen kelas merupakan suatu proses seleksi tindakan yang dilakukan guru dalam fungsinya sebagai penanggungjawab kelas dan seleksi penggunaan alat-alat belajar yang tepat sesuai dengan masalah yang ada dan karakteristik kelas yang dihadapi". ${ }^{10}$

Jadi, manajemen kelas sebenarnya upaya mendayagunakan seluruh potensi kelas baik sebagai komponen utama pembelajaran maupun komponen pendukungnya. Tujuan manajemen kelas pada hakikatnya telah terkandung dalam tujuan pendidikan. ${ }^{11}$ Secara umum tujuan manajemen kelas adalah penyediaan fasilitas bagi bermacammacam kegiatan belajar dan bekerja siswa dalam lingkungan sosial, emosional dan intelektual dalam kelas. Adapun tujuan manajemen kelas adalah agar setiap anak di kelas dapat bekerja dengan tertib sehingga segera tercapai tujuan pengajaran secara efektif dan efisien. ${ }^{12}$ Sementara itu, tujuan lain dari manajemen kelas sebagai berikut. ${ }^{13}$

\footnotetext{
${ }^{7}$ Arikunto dan Suharsimi, Prosedur Penelitian Suatu Pendekatan Praktik (Jakarta: Rineka Cipta, 2010).

${ }^{8}$ Bahri Syaiful Djamarah, Guru dan Anak Didik dalam Interaksi Edukatif (Jakarta: Rineka cipta, 2006).

${ }_{9}^{9}$ Munzier dan Harjani Hefni Suparta, Metode Dakwah, ke-3 edition (Jakarta: Kencana Prenada Grup, 2009).

10 Pupuh Fathurrohman, Strategi Belajar Mengajar (Bandung: Rafika Aditama, 2007).

${ }^{11}$ Djamarah, Guru dan Anak Didik dalam Interaksi Edukatif.

12 Arikunto dan Suharsimi, Prosedur Penelitian Suatu Pendekatan Praktik.

${ }^{13}$ Wiyani, Manajemen Kelas: Teori dan Aplikasi untuk Menciptakan Kelas yang Kondusif

(Yogyakarta: Ar-Ruzz Media, 4753).
} 
a. Memudahkan kegiatan belajar peserta didik.

b. Mengatasi hambatan-hambatan yang menghalangi terwujudnya interaksi dalamkegiatan belajar mengajar.

c. Mengatur berbagai penggunaan fasilitas belajar.

d. Membina dan membimbing peserta didik sesuai dengan berbagai latar belakang sosial, ekonomi, budaya serta sifat-sifat individunya.

e. Membantu peserta didik belajar dan bekerja sesuai dengan potensi dan kemampuan yang dimilikinya.

Menciptakan suasana sosial yang baik di dalam kelas, ada beberapa acuan bagi guru untuk mewujudkan gagasan/ide dan perilaku kreatif dalam manajemen kelas, yaitu sebagai berikut ${ }^{14}$ :

a. Mengkaji bahan ajar/materi pembelajaran yang akan disampaikan.

b. Mengakaji bentuk-bentuk pengelolaan kelas.

c. Memperhatikan hal-hal pengelolaan kelas terkait dengan pemberian dan membangkitkan perhatian dan motivasi peserta didik, mengembangkan keaktifan dalam pembelajaran, keterlibatan langsung peserta didik, pemberian pengulangan, pemberian tantangan belajar, pemberian balikan dan penguatan, serta perbedaan individual siswa.

d. Mengidentifikasikan permasalahan dan hambatan.

e. Membahas dengan kepala sekolah dan rekan guru lain untuk mencari alternatif pemecahannya.

f. Menyusun rencana kerja.

\section{Metode Penelitian}

Penelitian ini menggunakan pendekatan kualitatif. Penelitian ini dilaksanakan di SDIT Al Kautsar Madani Kota Batam. Subjek penelitian ini adalah 6 (enam) guru SDIT Al Kautsar Madani. Teknik pengumpulan data adalah dengan menggunakan observasi dan wawancara. Data dianalisis dengan menggunakan anlisis data kualitatif yaitu mereduksi data, penyajian data, dan menarik

\footnotetext{
${ }^{14}$ Iskandar Agung, Meningkatkan Kreativitas Pembelajaran Bagi Guru. (Jakarta: Bestari Buana Murni, 2010).
}

23 Jurnal Madania: Volume 9 : 1, 2019 (e-ISSN 2620-8210| p-ISSN 2088-3226 
kesimpulan.

\section{Hasil Penelitian dan Pembahasan}

Berdasarkan hasil observasi dan wawancara di atas, secara umum manajemen kelas yang dilakukan oleh guru SDIT AI Kautsar Madani Kota Batam sudah baik. Di SDIT Al Kautsar Madani Kota Batam pelaksanaan manajemen kelas sudah baik. Dalam proses pembelajaran guru tersebut sudah menjalankan tugasnya mulai menciptakan iklim belajar yang tepat sampai mengelola interaksi kegiatan belajar mengajar dengan baik. Walaupun ada beberapa kendala yang dihadapi guru dalam manajemen kelas. Manajemen kelas dimaksudkan untuk menciptakan lingkungan belajar yang kondusif bagi anak didik sehingga tercapai tujuan pengajaran secara efektif dan efisien. Ketika kelas terganggu, guru berusaha mengembalikannya agar tidak menjadi pengahalang bagi proses belajar mengajar.

Dalam proses belajar mengajar guru sudah mempraktekkan keterampilan manajemen kelas dengan baik, diantaranya mengadakan pendekatan secara pribadi dengan siswa, membimbing dan memudahkan belajar siswa, serta mengatur dan memonitor kegiatan pembelajaran. Guru selalu memotivasi siswa untuk belajar dengan baik. Jika ada siswa yang berbuat tidak baik guru menegur, sehingga perilaku siswa yang tidak baik tersebut tidak berkelanjutan sehingga kelas tidak menjadi kacau dan tidak kondusif. Sebagian guru mengalami kendala dalam mengelola kelas adalah saat siswa mengganggu proses pembelajaran dengan prilakunya yang tidak baik, sehingga anak-anak lain juga ikut terganggu.

Guru membimbing jika ada siswa yang belum paham materi yang didiskusikan. Selain itu guru juga sudah membangun komunikasi yang baik dengan tidak menjadikan dirinya sebagai satu-satunya yang mendominasi pembicaraan di kelas, tetapi guru juga memberi kesempatan pada siswa untuk berbicara.Ada beberapa kendala yang di hadapi guru SDIT Al Kautsar Kota Batam seperti yang diuraikan guru-guru kelas, bahwa kendala-kendala dalam manajemen kelas yang terjadi biasanya berkaitan dengan siswa. Kendalanya pada saat proses pembelajaran berlanngsung ada siswa yang membuat keributan Dikelas, tidak mau mendengar penjelasan dari gurunya dan Afi Parnawi; Pengetahuan Manajemen Guru... 24 
ada siswa tidak mau belajar. Kendala tersebut juga terjadi karena kurang kesiapan guru dalam manajemen kelas. Keberhasilan pendidikan bisa di lihat dari proses pembelajaran itu berlangsung, bagaimana guru mampu membangun manajemen kelas atau mengelola kelas dengan baik agar proses pembelajaran berjalan efektif, dan mampu memajukan atau mewujudkan tujuan pendidikan.

Secara umum, manajemen kelas bertujuan untuk menciptakan suasana kelas yang nyaman sebagai tempat berlangsungnya kegiatan belajar mengajar. Ada beberapa kendala yang dihadapi guru SDIT AI Kautsar Madani Kota Batam seperti yang diuraikan guru-guru kelas, bahwa kendala-kendala dalam manajemen kelas yang terjadi biasanya berkaitan dengan siswa. Kendalanya pada saat proses pembelajaran berlanngsung ada siswa yang membuat keributan dikelas, tidak mau mendengar penjelasan dari gurunya dan ada siswa tidak mau belajar. Kendala tersebut juga terjadi karena kurang kesiapan guru dalam manajemen kelas. Keberhasilan pendidikan bisa di lihat dari proses pembelajaran itu berlangsung, bagaimana guru mampu membangun manajemen kelas atau mengelola kelas dengan baik agar proses pembelajaran berjalan efektif, dan mampu memajukan atau mewujudkan tujuan pendidikan. Secara umum, manajemen kelas bertujuan untuk menciptakan suasana kelas yang nyaman sebagai tempat berlangsungnya kegiatan belajar mengajar.

Peranan guru sangat penting dalam pendidikan. Baik buruknya suatu pendidikan dipengaruhi oleh bagaimana seorang guru dapat menyampaikan atau mengajarkan ilmu pengetahuan serta nilai-nilai kehidupan yang mampu membawa peserta didik mewujudkan citacitanya. Terkait dengan pentingnya peran seorangguru, maka guru harus memiliki berbagai kemampuan, tidak hanya kemampuan akademik yang harus dimiliki oleh seorang guru, akan tetapi bagaimana seorang guru mempunyai kemampuan untuk memotivasi peserta didik, agar mau belajar yang nantinya akan meningkatkan prestasi serta cita-cita peserta didik.

Keberhasilan manajemen kelas yang dilakukan oleh guru bisa didukung oleh berbagai faktor. Diantaranya faktor sekolah dan juga faktor pribadi guru sendiri. Jika guru mempunyai kemampuan dan benar-benar ingin melakukan manajemen kelas dengan sungguhsungguh tentu hasilnya juga akan baik, namun jika guru hanya fokus pada kegiatan mengajar saja dan kurang memperhatikan kegiatan 
manajerial kelas, maka kegiatan pembelajaran pun tidak akan berjalan dengan maksimal. Selain itu, faktor sekolah juga turut memegang peranan dalam penyediaan fasilitas pendidikan yang memadai. Jika di sekolah tersedia fasilitas yang memadai tentu guru juga akan semakin mudah untuk melakukan manajemen kelas dengan lebih maksimal.

Guru diharapkan bisa mengatasi masalah-masalah yang membuat tidak kondusifnya kondisi kelas. Untuk itu, seorang guru harus memperhatikan komponen pengelolaan kelas dalam mewujudkan kelas yang kondusif. Berkaitan dengan fungsi atau peran guru untuk mengembangkan potensianak (guru sebagai demonstrator dan guru sebagai manajemen kelas), guru harusmengetahui betul potensi anak didik. Karena dari potensi itulah, guru menyiapkan strategi kegiatan yang sinergik dengan potensi anak didik. Strategi digunakan untuk mewujudkan kesuksesan atau keberhasilan tujuan pendidikan.

Selain penggunaan strategi secara tepat guru juga dituntut mampu untuk menggunakan dan memanfaatkan sumber daya yang ada, karena membangun manajemen kelas tidak hanya pada penggunaan strategi, akan tetapi bagaimana membangun manajemen kelas atau mengelola kelas itu dengan mengsinergikan semua potensi yang ada, baik dari potensi dan karakteristik guru sebagai pendidik itu sendiri, peserta didik yang mempunyai potensi dan karakteristik beragam, memanfaatkan media, sarana dan prasarana yang sudah tersedia maupun lingkunngan yang mempengaruhi berhasilnya sebuah tujuan pendidikan.

Dampak dari globalisasi ini juga yang telah mengakibatkan pergeseran dalam peran guru. Jika dulu guru hanya berperan sebagai orang yang mengajari, menggurui, dan sebagai makhluk serba bisa. Maka sekarang harus bergeser, peran guru menjadi sosok yang lebih memberikan motivasi, inspirasi, fasilitas serta kawan dialog bagi peserta didiknya. Guru sekarang ini dituntut lebih maju, lebih pintar, memahami perkembangan zaman dan sadar terhadap munculnya halhal baru.

\section{Kesimpulan}

Berdasarkan pembahasan sebelumnya, dapat disimpulkan hasil dari penelitian adalahGuru kelas di Gugus Bungong Seulanga Afi Parnawi; Pengetahuan Manajemen Guru... 26 
Kecamatan Syiah Kuala Kota Banda Aceh memiliki kemampuan yang baik dalam manajemen kelas tetapi ada beberapa guru mengalami kendala dalam manajemen kelas.Peran guru untuk mengembangkan potensi anak (guru sebagai demonstrator dan guru sebagai pengelola kelas), guru harus mengetahui betul potensi anak didik. Karena dari potensi itulah, guru menyiapkan strategi kegiatan yang sinergik dengan potensi anak didik.

Guru merupakan faktor penentu yang sangat dominan dalam pendidikan karena guru memegang peranan dalam proses pembelajaran, dimana proses pembelajaran merupakan inti dari proses pendidikan secara keseluruhan. Guru yang kreatif sangatlah dibutuhkan untuk mengembangkan suasana kelas yang kondusif yang dapat memberikan rasa senang, rasa nyaman, mengasyikkan, penuh keakraban, bersemangat dan lain sebagainya. Kendala-kendala dalam manajemen kelas yang terjadi biasanya berkaitan dengan siswa. Kendalanya pada saat proses pembelajaran berlangsung ada siswa yang membuat keributan dikelas, tidak mau mendengar penjelasan dari gurunya dan ada siswa tidak mau belajar. Kendala tersebut juga terjadi karena kurang kesiapan guru dalam manajemen kelas dan kurangnya memusatkan perhatian kapada siswa.Guru selalu memberi motivasi kepada siswa untuk belajar dengan baik. Jika ada siswa yang berbuat tidak baik guru menegur, sehingga perilaku siswa yang tidak baik tersebut tidak berkelanjutan sehingga kelas tidak menjadi kacau dan tidak kondusif.

\section{Daftar Pustaka}

A.M, Sadirman, Interaksi dan Motivasi Belajar Mengajar, Jakarta: Raja Grafindo Persada, 2012.

Agung, Iskandar, Meningkatkan Kreativitas Pembelajaran Bagi Guru., Jakarta: Bestari Buana Murni, 2010.

Arikunto dan Suharsimi, Prosedur Penelitian Suatu Pendekatan Praktik, Jakarta: Rineka Cipta, 2010.

Djamarah, Bahri Syaiful, Guru dan Anak Didik dalam Interaksi Edukatif, Jakarta: Rineka cipta, 2006.

Djamarah, Syaiful Bahri, Strategi belajar mengajar / Syaiful Bahri Djamarah dan Aswan Zain, pertama edition, Jakarta: Rineka cipta, 2010.

27 Jurnal Madania: Volume 9 : 1, 2019 (e-ISSN 2620-8210| p-ISSN 2088-3226 
Fathurrohman, Pupuh, Strategi Belajar Mengajar, Bandung: Rafika Aditama, 2007.

Hadi, M. Fahli Zatra and Zubaidah Zubaidah, 'Pemanfaatan Konseling Neuro Linguistic Programming dalam Mengatasi Kesulitan Belajar Siswa Sekolah Dasar', Jurnal Dakwah Risalah, vol. 26, no. 4, 2015, pp. 174-82.

Miftahuddin, Miftahuddin and Nofmiyati Nofmiyati, 'NILAI NILAI

PENDIDIKAN MORAL DALAM GURINDAM DUA BELAS KARYA

RAJA ALI HAJl', An-Nida', vol. 40, no. 2, 2016, pp. 89-99.

Mulyasa, Menjadi Guru Profesional. Bandung, Bandung: Remaja Kosdakarya, 2005.

Suparta, Munzier dan Harjani Hefni, Metode Dakwah, ke-3 edition, Jakarta: Kencana Prenada Grup, 2009.

Wiyani, Manajemen Kelas: Teori dan Aplikasi untuk Menciptakan Kelas yang Kondusif, Yogyakarta: Ar-Ruzz Media, 4753. 